\title{
Sportens væsen og uvæsen \\ - en analyse af sportens historiske regimer \\ i lyset af doping-krisen
}

Af Jeppe Loshak og Martin D. Munk

Hvis det kom frem i medierne, at der fandtes en udbredt praksis blandt passionerede frimærkesamlere for indtagelse af medikamenter, der $\emptyset$ gede deres præstation udi filatelien, ville det næppe give anledning til skandale af landsdækkende dimensioner. Anderledes er det, når der er tale om elitesportsfolk. Hvorfor denne forskel?

Doping-skandalen ved Tour de France i sommeren 1998 var et chok for ikke bare cykelsporten, men for den professionelle udøvelse af sport i det hele taget. Man sagde endda, at nu havde sporten $»$ mistet sin uskyld « - i den forstand at pengeinteresser havde bortledt sporten fra dens sande bane og sande væsen. Men har der ikke altid været eksterne interesser i sport? - og hvad er dette sportens vaesen egentlig for en størrelse?

I dansk sammenhæng handlede hovedparten af den efterfølgende debat dels om, hvordan det kunne komme så vidt inden for cykelsporten, og dels om hvordan man får gjort op med uvæsenet - altså en debat, der forudsætter modstand mod dopingfænomenet. Men blandt intellektuelle debattører er tillige opstået en debat, der omhandler selve dopingens legitimitet - eksempelvis eksponeret i Verner Møllers debatbog Dopingdjcevlen fra 1999.

Det er denne anden debat, vi vil interessere os for i det følgende. I denne debat optræder der selvsagt modstandere af doping, men oppositionen består her af posi- tioner, der anlægger en mere pragmatisk holdning: Doping er ganske vist kritisabelt og problematisk, men doping som praksis er tæt forbundet til almindeligt forekommende identiteter og værdinormer inden for eliteidrætten. Begge parter har, som vi skal se, en tendens til at associere deres argumenter til en ultimativ referent - et fundament der kan give endelig forståelse af idræt og sport og derved give debattørens argumenter en autoritativ rationalitet. Vi er her på sporet af selveste »sportens væsen « - og det er ikke tilfældigt, at dette lyder som navnet på en beboer i den platoniske verden af rene ideer. Vi har her at gøre med hvad man kunne betegne »social metafysik «, der danner grundlag for praksis inden for afgrænsede sociale sfærer - eksempelvis sporten. Der er ikke tale om metafysik i filosofisk forstand, men i det omfang, den betinger praksisformerne $i$ et givet felt, optræder den som var den »rigtig « metafysik. Det, der giver den anden debat sit momentum, er, at der tilsyneladende er uenighed om, hvad dette »sportens væsen« består i.

\section{Sporten som et socialt felt}

Eksistensen af social metafysik - f.eks. i sportens verden - er ofte betinget af en vis tavshed. Indgangen til det metafysiske domæne vogtes af bestemte ord - som sportens vaesen - der netop grundet sårbarheden og kontingensen har tabuets karakter. ${ }^{1}$ 
De repræsenterer et forestillet rum, der er fyldt med dette noget, der gør det sociale muligt - og som sådan er der tale om sakrale ord, der kun bør bruges, når situationens alvor kræver det. Hvis de nævnes, repræsenterer de under normale omstændigheder det sidste ord - der hvor al modsigelse ophører. Dette sikrer, at de værdier, der er centrale for en given social orden, kan opretholde deres urørlighed - også i en situation, hvor de kommer under pres. I en normaltilstand, hvor praksisformen forekommer naturlig, vil det som regel slet ikke være nødvendigt at mobilisere tabuet.

Anvender vi den franske sociolog Pierre Bourdieus terminologi, kan man anskue sportens verden som et socialt felt - et område, der adskiller sig fra den omliggende sociale praksis, ved at al handling inden for murene legitimeres alene ved feltets egen specifikke logik. ${ }^{2}$ Den centrale referent i et sådant kompleks betegner han doxa. Denne ikke-erkendte sociale metafysik danner grundlaget for de kapitalformer, der gør sig gældende i feltet, og som er specifikke for netop dette felt.

Hvis en kapitalform skal være legitim inden for et givet felt, skal den altså have karakter af uantastelig værdi, idet den refererer til doxa. Paradoksalt nok bliver dette mest tydeligt i situationer, hvor kapitalformerne antastes, som det har været tilfældet inden for cykelsporten og inden for sportsverdenen generelt siden 1998.

Der bliver rodet godt og grundigt rundt i sportens metafysik for tiden, hvorved den splintres i et antal fragmenter, som ved nærmere eftersyn viser sig at være rester af genkendelige historiske regimer. Disse regimer har ikke nødvendigvis noget fælles udspring, men kan tværtimod have store indbyrdes modsætninger - og endda have en historie af gensidige konflikter. ${ }^{3}$ Eller anderledes formuleret: De har ikke fælles oprindelse, og de har ikke i udgangspunktet haft samme legitime kapitalform.

Dannelsen af et felt sker historisk set ved, at »oversættelsen« og udvekslingen af elementer fra forskellige sociale strømninger får en hyppighed og intensitet, der giver omvekslingsforholdene mellem førhen adskilte værdiformer en nærmest automatisk karakter. Til sidst bliver det ikke længere aktuelt overhovedet at påpege forskellene $^{4}$ (Bourdieu 1996b). Således bliver det, der i udgangspunktet tilhørte forskellige historiske praksis- og diskursive former til én feltspecifik repræsentation, der nok kan have utallige variationer, men som er bundet sammen af én fælles metafysik eller doxa. Ifølge Bourdieu kan en sådan transformation kun ske ved at de oprindelige forskelle - ja, endda udspringene selv - er blevet glemt. Han kalder det feltets genesis amnesia - fødsel gennem glemsel. ${ }^{5}$ Egenlogikken i et stabilt felt og den relative ensartethed, hvad angår reglerne for socialt acceptabel adfærd, opstår således ved, at glemslen dækker over et antal latente selvmodsigelser. Disse kan under særlige omstændigheder atter komme frem i lyset.

Når sportens helhed og dermed dens entydige legitime kapitalform er truet for tiden, så ses dette blandt andet ved, at feltets genealogiske elementer på ny brydes efter års glemsel og relativ entydighed. De forskellige positioner i ovennævnte debat om dopingens legitimitet hævder alle, at deres version af sportens inderlighed og yderlighed, dens væsen og uvæsen, dens kerne og truslen mod denne kerne - er den sande forståelse af sportslig aktivitet.

Det, man troede var en harmonisk og udelelig enhed - dette sportens væsen - viser sig nu at være så modsætningsfyldt, at det risikerer at miste den særegne logik, der gjorde, at vi kunne personificere den $\mathrm{i}$ et »væsen«. Amnesien er ovre, og det er 
som om, vi atter mindes feltets konfliktfyldte fortid.

Kunne man forestille sig, at en lignende rystelse kunne ske inden for frimærkesamlingens felt? Også her kan man problematisere den sociale metafysik: Hvad er egentlig rationalet for at samle på betalingsbeviset for en forsendelse? - et brev skulle vel højst kunne legitimeres ved dets indhold! og hvad er rationalet for, at indehaveren af en bestemt selektion af mærker eller en bestemt viden om disse udmærker sig i forhold til en hvilken som helst anden? ${ }^{6}$

Alligevel forekommer en sådan rystelse usandsynlig - og årsagen er, at den omliggende verden ikke interesserer sig synderligt for, hvad der foregår inden for filateliens felt. Sporten derimod har fra sit udspring befundet sig i en stadig udvekslingsog omvekslingsrelation med omgivelserne. For at forstå dette nærmere kan vi atter tage en tur ind i Bourdieus teoribygning.

\section{Sociale felters anatomi}

Et socialt felt er som regel orienteret $i$ to dimensioner - en mængdemæssig og en polær. Den mængdemæssige er i udgangspunktet gammelkendt - opererende med positioner i henhold til kapitalmængde, uanset kapitalens art. Men det er den polære dimension, der giver modellen dens unikke karakter: Alle felter er orienteret i et rum, der findes mellem en kulturel og en $\varnothing$ konomisk pol. Ved den kulturelle pol findes den del af feltet, hvor kapital udelukkende er feltspecifik. ${ }^{7}$ Her er ingen transformation af kapital mulig, og positionering er her udelukkende intern. Agenter, der indtager disse positioner, er disponeret således, at de udelukkende søger anerkendelse af ligesindede, og de ønsker ikke at omsætte deres specifikke kulturelle kapital til andre kapitalformer uden for feltet. ${ }^{8}$ Bourdieu kalder dette fænomen for disinterestedness. Heroverfor står den økonomiske pol, der er orienteret såvel mod feltets specifikke kulturelle kapital som mod kapital, der er kurant i andre felter. Her er omsatteligheden af kapital i højsædet - dog således at agenter ved den $\varnothing$ konomiske pol inden for et bestemt felt er eksperter i omsætningsmulighederne for netop dette felts særlige kapitalform - ellers ville de slet ikke tilhøre feltet. Dette kaldes interestedness.

Kort sagt findes feltets egenart ved den ene pol og omsætteligheden og omsætningen af denne ved den anden. Heraf følger umiddelbart, at graden af autonomi for et felt på et givet tidspunkt afhænger af den kulturelle pols tiltrækningskraft. Bliver den $\varnothing$ konomiske kapital for dominerende, vil feltet nærme sig en tilstand af total omsættelighed, hvorved dets kapitalform mister sin unikke karakter, og i sidste instans vil feltet blive underlagt andre felter. Feltets potentiale for autonomi er altså at finde ved den kulturelle pol. Uden denne feltspecifikke kapital findes intet felt.

Felters autonomi kan på den anden side aldrig blive fuldstændigt realiseret. Man kan forestille sig en tilstand, hvor omgivelserne overhovedet ingen interesse har for feltets kapitalformer. I et sådant scenarie vil der slet ikke være nogen $\varnothing$ konomisk pol, og derfor kan man ikke tale om noget felt i den bourdieuske forstand. Felters autonomi er således altid relativ - og spørgsmålet er herefter, om filatelien overhovedet kan betegnes som et felt.

Det skal bemærkes, at man ikke med den $\varnothing$ konomiske pol alene skal forstå omsætningsmulighederne for de feltspecifikke kapitalformer til den mest kendte og mest udbredte $\varnothing$ konomiske fællesnævner nemlig penge - selvom disse ofte indtager en særlig teknisk rolle i omsætningen af kapital mellem felter. Når staten eksempel- 
vis bevilliger penge til ungdomsarbejde inden for idrætten, så er det fordi, idrætten her kan underordnes en given politisk interesse - f.eks. at sænke kriminaliteten eller fremme integrationen af indvandrere. Staten er en af de fremmeste agenter (eller rettere kompleks af agenter) i det, Bourdieu kalder magtfeltet - et priviligeret felt, der har let adgang til de fleste andre felter, som oftest i kraft af overlegen $\varnothing$ konomisk og symbolsk kapital. ${ }^{9}$

At det netop var et indgreb fra det politiske felt, i magtfeltet, der forårsagede rystelsen i cykelsports-feltet, skal følgende beskrivelse af begivenhederne omkring Tour de France i 1998 bevidne:

\section{Den ambitiфse sportsminister}

I 1997 overtog socialisten Lionel Jospin regeringsmagten i Frankrig. Jospin er protestant, hvilket $\mathrm{i}$ en fransk sammenhæng borger for høj moral! Den nye regering spillede fra sin begyndelse da også på de moralske strenge, der var til rådighed $\mathrm{i}$ 1990'ernes nye orkestrering af samfundet oven på 1980'ernes individualistiske og markedsliberale trend. For at opnå flertal i parlamentet havde socialisterne allieret sig med det lille kommunistiske parti, der således fik del i regeringsmagten med råderet over fire ministerier. Et af disse var ministeriet for ungdom og sport. I udgangspunktet ikke noget særligt magtfuldt ministerium, men den udpegede kommunistiske minister Marie-Georges Buffet, der var om muligt endnu mere moralsk disponeret end sin socialistiske overordnede, så i kampen mod dopingen en mulighed for at profilere sig og dermed erobre politisk kapital med udgangspunkt i investeringer i sit eget legitime resort - sporten. Tidligt i sin periode udtalte hun, at »...vi må nu vise, at den politiske vilje til at bekcmpe doping ikke bliver stående ved de gode intentioner. ${ }^{10}$ Sådanne udtalelser havde de sportslige organisationer hørt før, uden at der var sket det store, men denne gang blev der sat handling bag ordene. Ud over at tredoble budgettet til anti-doping-kampen og sende irettesættelser til de sportslige forbund havde hun en konkret slagplan: Hun ville slå ned på selveste Tour de France. I baghånden havde hun en lovgivning fra 1970'erne, der formelt kriminaliserede doping. ${ }^{11}$ Problemet bestod i at få de franske unders $\varnothing$ gelsesdommere til at effektuere lovgivningen. Hvordan dette lykkedes for Buffet, er ikke helt klart, men Lars Bøgeskov foreslår, at det er sket med opbakning fra justitsministeriet og ved at spille på især de yngre unders $\emptyset$ gelsesdommeres karriereambitioner. ${ }^{12}$ Taktikken var ikke risikofri. Man kunne risikere at få medierne og sportspublikum og i sidste ende selve folkestemningen imod sig.

Allerede i marts 1998 var en af TVMholdets biler blevet standset i Reims med en ladning EPO i bagagen, uden at det fik konsekvenser. Men i juli, da Tour'en gik i gang, havde der lige været fodbold-VM i Frankrig - ovenikøbet med værtsnationen som vinder - og folk var ved at være mætte af sport. Og da slog undersøgelsesdommeren i Lille ned på Festina-holdet.

\section{Aktionen}

Festina-holdet var på det tidspunkt et af de mest magtfulde hold i sporten. ${ }^{13}$ Det lå nr. et på verdensranglisten og havde i sin stald så fremtrædende ryttere som verdensmesteren Laurent Brochard, Vuelta-vinderen Alex Zülle og ikke mindst det store franske Tour-håb Richard Virenque. At slå til mod Festina var at gå direkte efter toppen. Om dette var en bevidst strategi fra myndighedernes side, kan man ikke sige med sikker- 
hed, men der er et par indicier, der tyder på, at det ikke var helt tilfældigt. For det første var det et klart signal om, at man mente det alvorligt og ikke var bange for nogen. For det andet er Festina et fransk hold, og ved at begynde her undgik de franske myndigheder at blive beskyldt for at stigmatisere udenlandske hold og holde hånden over deres egne. For det tredje var man sikre på, at der ville være gevinst - allerede i slutningen af juni blev holdets franske rytter Christophe Moreau testet positiv i en dopingkontrol, en sag som Den Internationale Cykelunion, UCI, tog så let på, at det ikke forhindrede Moreau i at stille op i Tour de France 14 dage senere. Desuden var holdets læge Eric Rychaert mistænkt for jævnlige $k \varnothing b$ af stoffer hos en berygtet apoteker.

Den 8. juli blev Festina-massøren Willy Voets bil stoppet på grænsen mellem Frankrig og Belgien med ca. 400 ampuller EPO og anabolske steorider - en episode som Festina i første omgang tørrede af på massøren selv. Men under pres fra politiet indrømmede Voet, at han havde handlet på ordre af sportsdirektør Bruno Roussel, og at doping-midlerne var beregnet til Festina-holdet.

Få dage senere ransagede politiet Festinas hovedkvarter i Lyon, fandt 18 ulovlige medikamenter og tog disse samt sportsdirektør Bruno Roussel og lægen Eric Rychaert med på stationen. Begge blev varetægtsfængslet og gennemgik forhør.

Allerede dette medførte hårde rystelser, både i det aktuelle Tour-felt og i cykelfeltet som helhed. Men mindre doping-sager er en fast bestanddel af strukturen i feltet - en kendt erhvervsrisiko. ${ }^{14}$ UCI optræder normalt som den balancerende agent, der smider afmålte portioner doping-sager for moralens løver - nok til at virke som ansvarlig myndighed, men ikke så meget at det rok- ker ved strukturens konsensus. Og da Festina-rytterne selv afviste ethvert kendskab til doping, regnede alle med, at det var nok for denne gang. Men de gjorde regning uden sportsminister Buffet og det franske politi. Den 15. juli indrømmede Bruno Roussel at stå bag systematisk doping på Festina-holdet.

\section{Den pragmatiske arrang $\phi r$}

På dette tidspunkt var cykelfeltet blevet politiseret - eller rettere, dets afgrænsning mod magtfeltet var blevet perforeret, ved at magtfeltets overlegne symbolske og fysiske kapital (politiet) begyndte at operere i det.

Som leder af Tour-arrangementet sad Jean-Marie Leblanc på en af de tungeste positioner i den del af cykelfeltet, der rækker langt ind i magtfeltet - med det man kunne kalde en pragmatisk position. Dertil hører en pragmatisk habitus. Han ville gøre alt for at bevare sit cykelløb, dets status og sin egen. For ikke at blive ramt måtte han selv markere distinktionen mellem det uanstændige og det tilladelige. I hvilken grad, han var under indflydelse af sine kontakter i magtfeltet, er usikkert. I hvert fald talte han i Buffets moralske termer, da han ved et pressemøde den 17. juli proklamerede, at han for at bevare »... etikken i cykelsporten og moralen i Tour de France ... $\ll^{15}$ måtte udelukke Festina fra fortsat deltagelse.

Dette var en katastrofe for deltagerne på Festina-holdet og en alvorlig sag for såvel det fortsat kørende Tour de France-felt som for hele sportens omdømme, og Leblanc var givetvis ikke glad ved situationen. Men ved at ofre Festina håbede han at have betalt den pris, agenterne fra det politiske felt forlangte. Men hvad stiller en pragmatiker op over for en kompromisløst idealistisk 
agent fra det politiske felt, en del af det dominerende magtfelt?

\section{Den altadende presse}

Politiet, tolderne og undersøgelsesdommerne var kun lige begyndt. Efter Festina fulgte TVM, Asics, Casino, Once - og sagerne ville ingen ende tage. Snart var det ikke blot myndighederne, der gennemtrævlede feltet. Også pressen begyndte at udfolde sig. Bl.a. gennemrodede medarbejdere fra France Television 2 nogle skraldespande uden for det hotel, hvor Asics-holdet residerede $i$ håb om at finde kanyler og andet godt. ${ }^{16} \mathrm{I}$ det hele taget havde sportspressen så kronede dage, at reportagerne sprængte sportssektionernes grænser og bredte sig lystigt rundt i medielandskabet - noget, der i øvrigt faldt i god jord i en agurketid, hvor verdens stående konflikter var taget på sommerferie sammen med de journalister, der dækker dem. ${ }^{17}$ Det skal retfærdigvis siges, at dele af pressen i overensstemmelse med deres position i medie-, cykel- og magtfeltet nuancerede problemstillingen og endda forsvarede cykelsporten eller dele af den. Men også dette kom pressen til gode, for næst efter en skandale er der intet som en hidsig debat. Pressen er et særegent felt, ved at dets praksis hovedsageligt består af diskursiv intervention $\mathrm{i}$ andre felter - og $\mathrm{i}$ skabelsen og opretholdelsen af en offentlighed. I sommeren 1998 kan man under alle omstændigheder konkludere, at da doping-sagen var blevet etableret af agenter fra magtfeltet, mangedoblede pressen dens momentum.

\section{De vrede ryttere}

Da det gik op for rytterne, at de alle som en var i fare for at blive udelukket, straffet, kriminaliseret og skandaliseret, reagerede de ved en kollektiv modaktion. Rytternes vrede rettedes dels mod pressen, og dels mod politiet, efter at det var blevet kendt, hvilke ydmygelser de tilbageholdte ryttere fra Festina og TVM havde måttet udstå. Den 27. juli var der fare for, at hele løbet måtte afbrydes, og dagens etape blev annulleret. Dagen efter lykkedes det kun ved intense forhandlinger at få løbet på benene igen, og dagen igennem kørtes der i slowmotion - afbrudt af gentagne sit-downstrejker. Til trods for at doping-fænomenet er kendt og nu også delvis erkendt i sit udstrakte omfang i feltet, følte rytterne en oprigtig vrede og indignation.

Der er i realiteten tale om en identitetskonflikt. Günther Lüschen fastslår, at doping er så udbredt inden for cykelsporten, at man ikke kan betegne den som en afvigende praksis. ${ }^{18}$ Den må derimod ses som noget normalt - i Bourdieus termer kan man sige, at ryttere, der med rette kan forvente at indtage magtfulde positioner i feltet, må være disponeret via deres habitus til at indtage præstationsfremmende medikamenter. Festina-rytteren Armin Meier udtalte efter Festina-holdets ekslusion af årets Tour de France, at »Ikke kun ni, men hundrede ryttere burde smides ud af Tour de France [...] Alle i cykelsport kender til doping $\ll{ }^{19}$ Præparaternes karakter af formel lovlighed eller ulovlighed kan naturligvis spille en vis rolle for den enkelte atlet, men hvis man vil være med i spillet, bevæger man sig under alle omstændigheder på grænsen mellem lovligheden og ulovligheden. Rytterne har et udpræget instrumentelt og objektiveret forhold til deres krop. Kroppen er et manipulerbart redskab, der, hvis den tunes perfekt, kan levere de påkrævede fysiske præstationer. Lægefaglig regenerering, overvågning og maksimering er i højere og højere grad ble- 
vet et supplement til den klassiske trænings-praksis i bestræbelsen på at producere kroppens optimum.

Når en ikke-elitesportsudøver konsulterer sin læge, har han som regel til formål at regenerere sin krop - føre den tilbage til normal ydeevne. Ideen om at maksimere kroppen kommer slet ikke på tale - den findes så at sige ikke i en læge-patient diskurs på lægmandsplan. ${ }^{20}$ Grænsen mellem regeneration og maksimering blandt såkaldt almindelige mennesker er altså rimelig klar. Hvis man skal maksimere sin krop, går man ikke til lægen, men derimod til et fitnesscenter eller til en kokain-pusher (det ene er lovligt, det andet kriminelt) - og man er klar over sin divergerende praksis. ${ }^{21}$ Elitesportsudøvere derimod er i besiddelse af en habitus, hvor man gennem lang tids socialisering er blevet disponeret for en kropsmaksimerende normalitet. Derfor er der her en flydende og uklar grænse mellem regeneration og maksimering.

Lægernes tilstedeværelse som faste medlemmer af cykelholdene er derfor umiddelbart doping-latent, hvis vi fastholder en definition, der siger, at doping er lig med unfair krops-maksimering via lægevidenskabelige medikamenter. Og mulighederne for doping er blevet mangeartede og blomstrende. For at holde orden i denne ustabile situation har UCI og Den Internationale Olympiske Komite, IOC, siden 1960'erne udarbejdet et semi-juridisk system med forbudslister, kontrolinstanser og straffe, der definerer grænsen mellem lovlighed og ulovlighed. Inden for cykelsporten har traditionen for doping imidlertid været så stærk, at det ikke har haft den store effekt. At denne tradition er reproducerende kan forstås ved simpel spil-teori: ${ }^{22}$ En ambitiøs rytter, der ved, at alle andre topryttere doper sig, vil have valget mellem selv at dope sig eller forlade spillet.
Festina-rytteren Alex Zülle sagde det helt klart: »Jeg havde to muligheder. Enten gik jeg med til at tage doping eller også stoppede jeg og blev maler igen «. Derfor vil alle topryttere være disponerede for at dope sig - og derfor må den ambitiøse rytters mistanke om, at alle doper sig, tillægges en vis sandsynlighed.

Det er derfor forståeligt, at rytternes vrede udelukkende rettes mod agenter fra udenforstående felter, medierne og politiet. Ifølge Marie-Georges Buffet er rytterne ofre for »falsk bevidsthed «. De burde i stedet rette deres vrede mod feltets egen struktur: »Cykelryttere er hele individuelle mennesker, som har ret til at komme til orde og

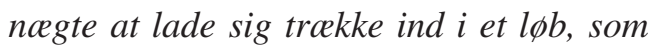
doping er en del af«, har hun udtalt. Hun betragter rytterne som arbejdere i kløerne på pengehungrende sponsorer og sportsdirektører. ${ }^{23}$ Man må give hende ret så langt, at rytternes protester antog en temmelig »proletarisk form « - i mangel af egentlig kapital, der havde gennemslagskraft i magtfeltet, måtte der tys til en trussel om arbejdsnedlæggelse - men hendes argument kan ikke undgå at forekomme i bedste fald retorisk motiveret. Det er diskutabelt, hvem der egentlig sidder inde med den falske bevidsthed, når modstridende værdier mødes. ${ }^{24}$

\section{Organisationernes selvransagelse}

I kølvandet på den mere håndgribelige og fysiske konflikt er der fulgt en mere diskursiv variant mellem de relevante organisationer - UCI, IOC, forskellige nationale idrætsorganisationer og pressen. Generelt må man sige, at brudfladerne i disse kampe er identiske med ovennævnte: Organisationer som f.eks. UCI, der befinder sig hoved- 
sagelig inden for cykelfeltet, opfører sig konservativt og defensivt, mens andre, såsom IOC og Danmarks Idræts-Forbund, der strækker sig ind over andre felter, er progressive og offensive. En undtagelse fra denne regel udgøres af Danmarks Cykle Union, hvis formand, Peder Pedersen, er en af de mest udfarende agenter i kampen mod dopingen. ${ }^{25}$ Kampene nåede en fase, hvor IOC - presset af diverse organisationer truede med at udelukke cykelsporten fra OL i Sydney, medmindre man fra UCI's side tog afgørende skridt i kampen mod dopingen. Hertil kom en kontrolleret respons fra UCI: Man ofrede lige præcis det, der skulle til for at tilfredsstille kritikerne. Cykelsporten blev ikke udelukket, men man fastholdt et betydeligt fokus på doping-problematikken.

Der ligger så status quo, og aktørerne inden for feltet kan håbe på, at de givne indrømmelser til magtfeltet vil være tilstrækkelige til at inddæmme yderligere indgreb. Men at det ikke er så ligetil at genvinde uskylden, vidner eksempelvis den danske doping-debat om. Her er der ikke tale om nogen forsoning. Tværtimod bliver der trukket streger i sandet, der tydeligere og tydeligere tegner modsætningerne mellem sportsfeltets historiske regimer. Vi vil nu fors $ø$ ge at analysere disse divergerende positioner.

\section{Sportens vaerdikompleks}

Regimerne, der har været afgørende i dannelsen af et selvstændigt felt, der socialt organiserer sport og idræt samt dette felts underliggende subfelter - heriblandt cykelsportsfeltet - kan inddeles i to hovedtyper: de socialiserende og de transcendentale. (Se Figur 1).

De socialiserende regimer kan igen underopdeles i to regimer: det utilitaristiske regime og det demokratiske regime. Begge disse har deres diskursive klimaks i politiske teorier fra oplysningstiden - selvom deres rødder strækker sig meget længere tilbage i tiden. I praksis er de stadig overmåde dominerende i hele det sociale rum.

Fælles for de socialiserende regimer er deres institutionaliserede tiltro til værdien af menneskeligt nærvær. Det gode liv kan realiseres i nuet eller i fremtiden her i denne verden og blandt menneskene - og kroppen har i denne forbindelse en karakter af positivitet: Realiseringen af kroppen er et led i realiseringen af mennesket - både individuelt og socialt. Men inden for sportsfeltet optræder også regimer, hvor kroppen er en hindring for selvets realisering, og hvis mytiske materiale hviler på en forestilling om transcendens.

Disse transcendentale regimer har ikke nogen forbindelse til historiske politiske regimer fra oplysningstiden. De hviler tværtimod på den slags forestillinger om frelse i det hinsides, som rationalisterne gerne henviste til den »mørke middelalder « med dens overtro og ufornuft. Ikke desto mindre overlevede de i rationalitetens skygge - i kristendommen, i kunsten og altså også i sporten. ${ }^{26}$

\section{Kroppen og den sociale nytte}

I det utilitaristiske regime underlægges al nutidig praksis en mere eller mindre abstrakt evalueringsproces, der - i det mindste teoretisk - kan reducere aktiviteter i samfundet til målbare størrelser i henhold til den universelle parameter: nytteværdi. Herefter er sociale aktiviteters legitimitet proportional med deres bidrag til den samlede samfundsnytte. Utilitarismens mål er en forhøjelse af samfundsnytten.

Under denne logik bliver kroppen et 
Figur 1.

\begin{tabular}{|c|c|c|c|c|c|}
\hline \multicolumn{2}{|c|}{ Regime } & \multirow{2}{*}{$\begin{array}{l}\text { Felt-intern } \\
\text { vardi }\end{array}$} & \multirow{2}{*}{$\begin{array}{l}\text { Talemåde } \\
\text { »En sund sjæl i } \\
\text { et sundt } \\
\text { legeme« }\end{array}$} & \multirow{2}{*}{$\begin{array}{l}\text { Omscettelighed } \\
\text { - stat } \\
\text { Folkesundhed } \\
\text { Produktion } \\
\text { Militær m.m. }\end{array}$} & \multirow{2}{*}{$\begin{array}{l}\text { Omsattelighed } \\
\text { - marked } \\
\begin{array}{l}\text { Livsstil } \\
\text { (individuel } \\
\text { sundhed) }\end{array}\end{array}$} \\
\hline Sociale & Utilitaristisk & & & & \\
\hline & Demokratisk & $\begin{array}{l}\text { Samvær og } \\
\text { fairness }\end{array}$ & $\begin{array}{l}» \text { Tab og vind } \\
\text { med samme sind }\end{array}$ & $\begin{array}{l}\text { Demokratisk } \\
\text { opdragelse }\end{array}$ & $\begin{array}{l}\text { Livsstil } \\
\text { (fan-kultur) }\end{array}$ \\
\hline \multirow[t]{2}{*}{$\begin{array}{l}\text { Tran- } \\
\text { scenden- } \\
\text { tale }\end{array}$} & Asketisk & $\begin{array}{l}\text { Offervillighed } \\
\text { og rekorder }\end{array}$ & $\begin{array}{l}\text { » øjere, } \\
\text { hurtigere } \\
\text { længere« }\end{array}$ & $\begin{array}{l}\text { Nationale } \\
\text { symboler }\end{array}$ & Underholdning \\
\hline & Dramatisk & $\begin{array}{l}\text { Spænding og } \\
\text { skønhed }\end{array}$ & $\begin{array}{l}\text { »De små } \\
\text { marginaler« }\end{array}$ & Ventilfunktion & Underholdning \\
\hline
\end{tabular}

redskab for tilvejebringelsen af $\varnothing$ nskede samfundsmæssige målsætninger: en stærk hær til sikring af nationens fremtid, en kompetent arbejdsstyrke til forøgelse af produktionen, fødedygtige kvinder til opretholdelse af reproduktionen osv.

I dag er det utilitaristiske regime delvis blevet individualiseret, hvorefter vi måske kan benævne det sundhedsregimet. ${ }^{27}$ Den enkelte mobiliserer sin sunde krop og sin sunde sjæl i et beredskab, der kan realisere individuelle mål. Inden for sportsfeltet vejer dette regime især tungt inden for fitness- og work-out-kulturen, men den opererer også inden for en stor del af den såkaldt folkelige idrætsudøvelse. En afg $\varnothing$ rende pointe er her, at selvom objektet for sundheden er individet, er regimet stadig af kollektiv art (det er regimer generelt): Dyrkelsen af egen krop bliver et socialt symbol - en værdi der kan anvendes som kulturel kapital såvel i sportsfeltet som i andre relevante felter. ${ }^{28}$

\section{Kroppen og det sociale fallesskab}

Selvom det må være indlysende for enhver, at forskellene mellem mennesker kan være meget store på mange planer - fysisk, mentalt, socialt - så hævder det demokratiske regime hårdnakket, at alle er lige hvilket dog slet ikke betyder, at de er ens. Dette paradoks har sin egen skønhed: Vi er lige trods alle forskelle, og trods alle uenigheder har alle på en måde alligevel retten på deres side. ${ }^{29}$ Der er altså ikke i udgangspunktet tale om en homogen demokratisk masse, men i stedet om en vis distance i mellemmenneskelige forhold. Diskursivt kendes denne distance bedst fra den middelalderlige adels æresbegreber og senere $\mathrm{i}$ begreber som noblesse og gentlemanship. Kamp mellem mænd ritualiseres og får form af et spil, hvor deltagelsen er vigtigere end sejren. Selvom spillet har vindere og tabere, dikterer tabuet, at denne inddeling $\mathrm{i}$ virkeligheden ikke findes - der er kun vindere. ${ }^{30}$ Således skabes homogenitet ved distance. Selve begrebet sport har 
rod i denne kultur: Den kropslige udfoldelse har form af en leg, der kun har mening $\mathrm{i}$ legens socialitet - i modsætning til det utilitaristiske regimes kropsudfoldelsesformer, idræt og gymnastik - hvor udfoldelsen har produktive mål.

I den danske sammenhæng har de to sociale regimer dannet knopskydninger, der har løsrevet sig fra deres respektive ophav og dannet en stærk koalition inden for sportsfeltet - og det er i høj grad styrken i denne syntese, manifesteret ved de folkelige idrætsforeninger, der organisatorisk er samlet under især DGI, ${ }^{31}$ der betinger, at feltet har en årelang historie af relativ autonomi. Eksterne interessenter fra det politiske felt har ganske vist fra tid til anden interveneret i feltet i folkeåndens, folkesundhedens eller nationens navn, men dette er næsten altid sket på regimets egne diskursive betingelser. Man kunne kalde det for den fortsatte dialog mellem feltet og dets aner. Dette skal ikke forstås således, at der ikke fandt reelle magtkampe sted om værdier, positioner og kapitalformer, men således at disse i den historisk aktuelle situation blev tabuiseret eller miskendt, så indsatsen forekom at være humanistisk og rationelt motiveret. Og her kunne kompleksets utilitaristiske momenter paradoksalt nok sikre feltet en grad af selvstyre trods de gentagne interventioner: Så længe idrætten gjorde sig anvendelig, fik den lov til selv at bestemme farten.

\section{Frigфrelsen fra kroppen}

Fra Max Webers essay om den protestantiske etik kender vi forbindelsen mellem askese og transcendens. I perioden domineret af den augustinske forståelse af kristendommen optræder kroppen som syndens locus og dermed som muligheden for fortabelse - frelsens antagonisme. Den dy- dige, der bestræber sig på at realisere frelsens mulighed, må derfor indstille sig på at kontrollere kroppens tilbøjeligheder for i sidste instans at kunne frigøre sig fra denne. At denne kropslige negativitet kunne danne grundlag for en social positivitet, er der håndfast empirisk dækning for. De utallige afbildninger af helgener og deres gerninger vidner om en kolossal popularitet - og denne var netop baseret på beretninger om almindelige mennesker, der gennem ekstrem kropslig afholdenhed og fornægtelse ophøjes til herrens højeste form for nåde.

Inden for sportens verden repræsenteres det asketiske regime ved den rationelle og ofte videnskabelige form, hvormed elitesportsfolk viser deres offervillighed. De er parate til at presse deres kroppe til ydeevnens yderste grænser. Ofte udvikles hele livsformer på dette grundlag, præget af kostrestriktioner, lægetilsyn og forordninger, der regulerer udøverens hverdag i større eller mindre omfang. Man kunne her indvende, at disse fænomener skal forstås som udøverens kropslige mobilisering til en professionaliseret og ekstremt resultatorienteret konkurrencesport, og at der således ikke er tale om et regime baseret på askese alene. Der er da heller ingen tvivl om, at sådanne faktorer spiller med i den nuværende indretning af sportsfeltet, men vi forsøger her at isolere bestemte mulighedsbetingelser for sportsudøveres dispositioner for selvopofrelse - noget der netop gør dem egnede til succesrig deltagelse i professionel sport.

Inden for visse sportsgrene er denne form for transcendens tillige et afgørende moment i gennemførelsen af selve sportsbegivenheden. I discipliner som langdistancel $\varnothing b$, langrend, enkeltstarter i cykelsporten, triathlon og andre ekstremsporter deltager publikum $i$ begejstringen over at- 
letens overskridelse af det menneskeligt mulige. Og dette fokus på overskridelse er tydeligst institutionaliseret i sportsgrene, der rutinemæssigt dyrker rekorden: atletik, svømning og vægtløftning.

\section{Kroppen i spillet}

Endelig er der det dramatiske regime, der indebærer en helt anden form for transcendens - nemlig spillet, udfordringen og den rituelle kamp. Dette regime kan bedst illustreres ved at analysere det efterhånden kendte mundheld inden for sportsverdenen: de små marginaler. Begrebet peger $\mathrm{i}$ to retninger. Dels ligger der et implicit $\varnothing n-$ ske fra udøvere og ledere o.a. i idrætten om at kunne minimere usikkerheden og tilfældigheden i udfaldet af sportskampe, således at man bedre kunne kalkulere resultaterne i henhold til antagne succeskriterier personlige, klubmæssige, nationale eller forretningsmæssige. Men det betegner samtidig eksplicit netop den brøkdel af ren hasard, som man aldrig kommer til livs og vel at mærke uden hvilken der slet ikke ville være tale om sport. Det drejer sig om fascinationen af den uafklarede umiddelbare fremtid.

I den franske filosof Jean Baudrillards termer er det her, alle investeringer og deres produktive logik mister deres rationale og forvandles til indsatser $\mathrm{i}$ et rent spil. ${ }^{32}$ Den bevidste aktive dyrkelse af denne form for fascination hylder en $\varnothing j$ jeblikkets sanselige transcendens uden objekt, og den er derfor af æstetisk karakter. Nogle vil påstå, at alle gode historier har en pointe og måske en morale (man får noget med hjem), men selve historiefortællingen ville være dødfødt, hvis ikke den hvilede på det uafklaredes inciterende princip. Det arrangerede møde mellem menneskelig vilje og dennes latente usikkerhed - mellem kamp og spil - har i utallige kulturer udgjort et refugium fra samfundets krav om kausal linearitet - og i de moderne samfund fungerer sporten som den vigtigste sfære, hvor denne form for udfrielse er systematisk ritualiseret. ${ }^{33}$

\section{Sportsfeltets integration}

Afgørende for den videre analyse af sportsfeltets rystelse er, at ovenstående fire regimer opfattes som feltets interne mulighedsbetingelse. De oprindelige modsætninger mellem regimerne er inden for feltet blevet opløst ved århundreders intensivering af deres indbyrdes omsættelsesmulighed, og de værdier, de afspejler, har erhvervet en indbyrdes korresponderende og integrativ karakter. Til analyseformål kan man skelne mellem fire typer feltinterne kulturelle kapitalformer, svarende til de fire regimer: Det utilitaristiske regime bærer værdien kropslig effektivitet, det demokratiske regime bærer værdierne samlende social kraft og fair play, det asketiske bærer værdierne offervillighed og rekord og det dramatiske bærer værdierne spaending og skønhed.

Men pointen er her, at disse værdier indtil for nylig har konvergeret $i$ et sammenhængende kompleks, der måske nok er blevet analyseret af akademiske specialister, men som i den praktiske sportsudøvelse samt dennes synliggørelse og popularisering over for tilskueren har haft én samlet metafysisk eller doxisk karakter - og dermed har optrådt som ren feltspecifik logik og værdi. Kampene og positioneringer i feltet har drejet sig om erhvervelse og forbrug af kapital, der er formuleret i denne værdis parametre. 


\section{Sportsfeltets eksterne interessenter}

Når felter overlapper hinanden, er det tit vanskeligt at afgøre, hvilket af dem der er den aktive part, og hvilket der bliver overlejret. Som tidligere omtalt er de socialiserende regimer dominerende i hele det sociale rum og dermed yderst virksomme i andre felter - og der har gennem tiden fra sportsfeltets skabelse og frem til vore dage været hyppig omsætning af kapitalformer mellem sportsfeltet og andre relevante felter (magtfeltet) - eller hvis man helt proforma antager en simpel funktionalistisk synsvinkel: Felterne udfører opgaver for hinanden til gensidig fordel..$^{34} \mathrm{I}$ de fleste europæiske lande findes der specialiserede statsorganisationer, hvis primære opgave netop er at tilrettelægge sådanne udvekslinger i samarbejde med repræsentanter fra sportsfeltet.

\section{Sportens ekspansion}

Dertil skal lægges, at inden for de sidste 20 år har dyrkelsen af kroppen som autenticitetens eksklusive habitat opnået stor udbredelse i hele det sociale rum. Denne trend har gjort det muligt for sportsfeltets eget værdisæt at opnå stor omsættelighed bredt i samfundet - med dertil hørende ekspansionsmuligheder for feltet som sådan. Det er blandt andet i sammenhæng med denne popularisering af den rene kropslighed, at man kan forstå sportens kommercialisering. Der har ganske vist været tilskuere til sportsbegivenheder i hele feltets historie, men der er især inden for de sidste 30 år sket en gradvis forandring i måden, dette er foregået på.

Tilskueren kan i udgangspunktet tænkes som en person, der på et eller andet tidspunkt i sin livsbane selv har været eller vil blive en deltager - eller som en person, der er knyttet til en eller flere af deltagerne ved personlige sociale bånd. På tilskuer-tidspunktet deltager personen imidlertid ikke, men lever så at sige med fra sidelinjen. I det øjeblik, de bevægende kroppe først og fremmest er rettet mod at tilfredsstille dette blik, taler man om en tilskuersport. Karakteristisk for denne er, at sporten og idrætten nu får mulighed for at blive solgt som en vare på et marked til et anonymt publikum. Den bliver omsættelig til økonomisk kapital.

I det omfang, kroppen forvandles til et beskuerobjekt, får den idrætslige og sportslige udfoldelse altså karakter af en teaterforestilling med et betalende publikum. Sport ændres fra først og fremmest at være en aktivitet baseret på felt-interne regler til en forestilling - en arrangeret kamp mellem udvalgte kropseksperter til fornøjelse for et publikum, der finder æstetisk nydelse $\mathrm{i}$ at betragte den symbolske kamp eller opnår livsfylde i en identifikation med en af udøvelsens parter. ${ }^{35}$ Hermed ændres idræt fra en dyrkelse af den konkrete krop til en dyrkelse af kroppen in abstraktum. Og dette åbner mulighed for en omfattende visualisering af feltets interne drivkræfter, der således frigjort kan ekspandere i det sociale rum i virtuelle simulerede former.

\section{Den фgede omsattelighed}

Sportens ekspansion i det sociale rum i form af audiovisuel replika er tæt knyttet til tv-mediets evne til at gengive »reelle« manifestationer i virtuel form. Eller som Bourdieu skriver: Man ser faktisk ikke begivenheden, men man ser heller ikke, at man ikke ser den. ${ }^{36}$ Sådanne tv-billeder er i de sidste årtier blevet »et kommercielt produkt, der adlyder markedets logik, og altså bor udtankes sådan, at de kan nå og 
laengst muligt fastholde det størst mulige publikum «. ${ }^{37}$ Den sport, der udøves under disse betingelser, befinder sig altså ovre ved feltets $\varnothing$ konomiske pol - der hvor omsætteligheden af kapitalformerne (værdierne) er alfa og omega. Hvilken indflydelse har denne glidning så haft på sportsfeltet?

For det første har det ændret feltet eksternt $-\mathrm{i}$ forholdet til andre felter. Som en iagttager har bemærket: »Idratten har $i$ hele dette århundrede varet en kolossal succes $\ll{ }^{38}$ Ekspansionen i det sociale rum skal ses som en faktuel begivenhed. At det de sidste 20-30 år hovedsageligt er sket virtuelt, skal ikke forlede os til at undervurdere udvidelsens vægt og dens ændring af styrkeforholdene felterne imellem. Virtualiteten i omsætningsrelationerne er nemlig ikke noget, der begrænser sig til sportsfeltets udvekslinger med sine omgivelser. Det er så at sige blevet en fælles betingelse for de afgørende udvekslinger i hele det sociale rum - det virtuelle har fået reelle sociale implikationer. Sportsfeltets totale kapitalbeholdning er vokset drastisk sammenlignet med omgivende felter - og antallet af omgivende felter, hvis kapital er konvertibel med sportsfeltets, er kraftigt forøget: Tøj- og skomarkedet, medie-branchen, helse-sektoren, kommuner, aktiemarkeder og kunstnere - alle kan de drage nytte af sporten - og den af dem.

Sportens $\varnothing$ gede salgbarhed har desuden implikationer for feltets interne konfiguration. Når tiltrækningskraften til den økonomiske pol øges i et felt, er det et afgørende spørgsmål for feltets balance, om den kulturelle pol kan mobilisere en tilsvarende forøgelse af felt-interne og autonome værdier. ${ }^{39}$ Når der er udsalg, må man enten have kolossale lagre eller en ny kollektion på vej - ellers er der tale om et ophørsudsalg. Betingelsen for, at sportsfeltet i hele det 20. århundrede har kunnet være så stor en succes uden at blive opløst ved den $\varnothing$ konomiske pol af sin stigende omsættelighed, er, at syntesen af kulturelle værdier fortløbende har været tilstrækkelig autonom og dynamisk til at opretholde og forny sit autoritative særpræg og sin legitimitet.

\section{Den radikale omsattelighed}

Men i de sidste 15-20 år har udvekslingerne ved den $\varnothing$ konomiske pol antaget en form for institutionalisering, der svarer til den, der hersker i produktionserhvervene. Adskillige sportsgrene er blevet professionaliseret; store mesterskaber er blevet tilrettelagt og styret $i$ henhold til tv-transmissionernes krav vedrørende sendetidspunkter og udvalg af sportsdiscipliner; klubber er blevet til virksomheder, hvor bundlinjerationalet er den dominerende motivation; man har talt om at oprette en europæisk superliga i fodbold, hvor de store klubber uden risiko for nedrykning kan koncentrere sig om det forretningsmæssige; sportsgrene uden den store publikumsappel ændrer deres regelsæt og organisation for bedre at kunne sælge varen - og få del i pengene - og endelig kan sportsstjerner bruge sporten som afsæt for karrierer i showbranchen (se dog Munk 1999).

Bourdieu kalder ligefrem disse tendenser for en industrialisering af idratsproduktionen. ${ }^{40}$ I stigende grad bliver feltet gennemtrængt og styret af interessenter, for hvem den rene pengeøkonomi har primat.

Spørgsmålet er så, om denne økonomisering af feltet undergraver dets mulighed for autonomi. Eller som kritikerne spørger: Er sporten ved at blive en del af underholdningsbranchen? For at undersøge disse spørgsmål vil vi atter vende os mod doping-problematikken. Bourdieu skriver: 
»Konkurrenceidratten ivarksatter mere og mere en industriel teknologi, der sigter mod at forvandle den menneskelige krop til en effektiv og utrcettelig maskine ved at mobilisere forskellige biologiske og psykologiske videnskaber. Konkurrencelogikken mellem de nationale hold og mellem staterne nodsager $i$ stadig højere grad til at ty til forbudte stimulanser og tvivlsomme traningsmetoder ${ }^{41}$

Men hvilken position taler den her normative Bourdieu selv fra? Hvem er det, der siger, at disse stimulanser og træningsmetoder er eksterne trusler mod feltet? Billedet af kroppen som en effektiv og utrættelig maskine knytter sig i det mindste tæt til det utilitaristiske regimes favorisering af den anvendelige og nytteproducerende krop og har konkurrencelogikken ikke altid været en del af sportens dramatiske habitus? $?^{42}$

\section{Debat-positionerne}

Ifølge Verner Møller har atleterne i cykelsporten lige fra starten benyttet sig af opkvikkende miksturer og præparater, der i dag ville blive betegnet som doping - og $\mathrm{i}$ stedet for at placere årsagerne i kommerciel intervention er det $\gg . .$. oplagt at søge forklaringen $i$ sporten selv, narmere bestemt $i$ relation til: Viljen til sejr. Viljen til at kunne konkurrere og prastere maksimalt ${ }^{43}$ Denne vilje er altså - ifølge Møller - ikke resultatet af en ydre påvirkning, men har tæt tilknytning til idrætten selv. For at være elite-idrætsudøver (Møllers udgave af sportens væsen findes i sin reneste form på eliteniveauet, hvorfra den så at sige diffunderer ud over hele feltet) må man være særligt disponeret over for risikobetonet aktivitet:
»Det er afgørende for at forstå sportsfolkenes risikovillighed at man forstår resultatets essentielle karakter [...] Viljen til at skabe resultater og således gøre sig som sportsmand - ambition med andre ord - er drivkraften i elitesport. Og ambitionen må have karakter af besattelse, hvis den skal indfries «. ${ }^{44}$

Møller bruger Georges Batailles som vidne på, at denne ambition stiler mod helt andre og højere mål end de økonomiske: Der er tale om et religiøst ritual, hvor ofringen den »unфdvendige uproduktive forødelse" - skaber et frirum i et samfund præget af $»$ den universelle tarvelighed $\aleph^{45}-\mathrm{dvs}$. nyttefiksering, påholdenhed og akkumulation:

»Op gennem moderniteten helt frem til vor tid har fritidsaktiviteter - og ikke mindst sport-fungeret som et sarligt reservat for denne $\phi$ dselhedens mening $«{ }^{46}$

Således disponeret for ambition, risikovillighed og ødselhed er det forståeligt, at eliteidrætsfolk tager alle tænkelige midler i brug - og dette sker vel at mærke i overensstemmelse med sportens inderste væsen - mener Møller.

Splintringen af sportsfeltet giver som tidligere nævnt anledning til stridende diskursive positioner, der hver for sig rendyrker deres version af sportens inderlighed og yderlighed - dens væsen og uvæsen - i henhold til feltets historiske regimer. Verner Møllers version af sportens inderlighed er eliteidrætsmennesket, der alene i kamp mod den universelle tarvelighed med dødsforagt overskrider sine menneskelige begrænsninger og hengiver sig til den berusende фjeblikkelighed. Hans version af yderligheden er så netop denne universelle tarvelighed, der med sin nyttefiksering har sat sig på sporten - sundhedsapostlene og 
de der vil bruge sportsfolk som moralske forbilleder og sporten som samfundsopdragende redskab. I vor regime-model må vi placere Møller i den transcendentale afdeling med hovedvægten i det asketiske transcendentale regime.

I en kritisk kommentar til Dopingdjocvlen skriver idrætsforskeren Claus Bøje, at Møller »glemmer fuldstandigt, at sportens fortalling grundlaggende refererer til kampen; og dermed dybest set til en konfrontation eller dialog mellem enkeltpersoner eller hold, hvor fascinationskraften kun $i$ begranset fald er afhoengig af dopingrelaterede forbedringer « ${ }^{47} \mathrm{I}$ Bøjes optik får sporten først mening, når den optræder som arena for mødet mellem forskellige akt $\varnothing r e r$, og den har således primært et socialt rationale. Dertil kommer den etiske dimension:

»Sportens iscenesattelse udgør en central kult i det 20. århundrede, som ikke lader sig henvise til et aestetisk foretagende. Den udgør en uhyre indarbejdet episk fortalling om det gode, det sande, det skønne og det hellige. Derfor er sporten forst og fremmest et ideelt foretagende, som reprasenterer centrale myter om livets mening «. ${ }^{48}$

Både Møller og Bøje benytter sig af religiøse termer, hvilket må tolkes som, at de betragter sig som fortolkere af sportens centrale mulighedsbetingelser, men de religioner, de anråber, er vidt forskellige. For Bøje indgår sporten i skabelsen af det gode samfund - eller i det mindste i forestillingen om denne socialitet. Gennem en mangeårig social forhandlingsproces har vi dannet regler for, hvad der er godt og skidt, og ifølge disse regler er eksperimenterne med den menneskelige krop uacceptable ikke alene er det snyderi og usundt, det er også inhumant og asocialt.
På trods af talen om det socialt set gode kan Bøje ikke entydigt placeres i det utilitaristiske sociale regime (for at finde klare fortalere for dette standpunkt, måtte vi nok opsøge skribenter, der favoriserer de rent sundhedsmæssige aspekter ved sporten). For Bøje er sporten først og fremmest en iscenesættelse af moralske fortællinger uanset substansen af denne moral, og sporten har dermed primært en kommunikativ funktion i sociale udvekslinger og ritualer. Man kan kalde ham for det utilitaristiske regimes meta-etiker - men i det omfang, han træder ned fra sin meta-position og tager konkret stilling til aktuelle begivenheder, bliver han faktisk en talsmand for idrættens sundhedsrationale. Således sammenligner han de dopede cykelryttere med det kendte grimme billede af medicinerede svin: »De dopingstruttende svin udfordrer vores forestillinger om sundhed og etik. De udg $\phi r$ en dårlig fortalling ${ }^{4} .{ }^{49}$

En anden idrætsforsker, der fokuserer på det sociale, er Henning Eichberg. For ham er kropsligt nærvær en særegen demokratisk egenskab. Demokrati er for ham noget, der undflyr de store teknokratiske og bureaukratiske systemer, hvad enten disse findes i markedsregi eller i statsregi. Den dopede krop er for ham en oprindeligt demokratisk krop, der er blevet taget til fange af sådanne videnskabelige regimer, der søger at perfektionere den. Dermed mister den sit menneskelige nærvær og bliver objekt for inhumane abstrakte projekter. Markedet og staten fokuserer kun på det empiriske menneske - dets svagheder og utilstrækkeligheder - og udhuler derved demokratiets mulighed:

"I forhold til denne udfordring af demokrati som livsform har kroppen en central stilling. Vi har granser, vi er svage, vi kan ikke nå det hele - det ved vi empi- 
risk. Men der er også det paradoksale, at menneskets liv er baseret på menneskets kropslige eksistens. Kroppen er vor tilgang til verden og til hinanden, til samfundet $\ll .{ }^{50}$

Den demokratiske kropslighed repræsenterer en »tredje vej« mellem stat og marked - noget der er tæt forbundet med ideen om et »civilsamfund «, hvor mennesket har den eneste relevante frihed - friheden fra systemerne - og hvor »Doping er [...] et modbillede mod demokratiets kropslighed. Vi er ikke engle, vi har granser, vi har farve og vi kan sige »du« til hinanden «. ${ }^{51}$ Eichberg kan placeres som talsmand for det demokratiske sociale regime.

Vi mangler stadig en repræsentant for det dramatiske regime. ${ }^{52}$ Dette regime har som nævnt i diskursiv forstand ført en skyggetilværelse sammenlignet med de $\emptyset$ vrige, og denne diskretion har på paradoksal vis sikret det en uantastelighed, der stadig er temmelig intakt. Hvad enten sport opfattes som socialiserende praksis, som sundhedsskabende aktivitet, som national identifikation, som profitskabende forretning, som hyldest til kroppens autenticitet eller som individets grænsebrydende mulighed, er der ingen, der for alvor problematiserer, at der må være et element af spændingen ved konfrontationen med den umiddelbare uafklarede fremtid. At der ikke er nogen, der i deres versioner af sportens væsen i nævneværdig grad har italesat denne faktor, har ved den særlige omvendte logik, der gælder for doxiske fænomener, sikret dens fortsatte regime.

\section{Konklusion}

Udfordringen fra den voksende omsættelighed truer med at udslette den amnesi, der var forudsætningen for et relativt ho- mogent felt med en egenlogik. Hukommelsens vækkelse fører til en reaktivering af de divergerende positioner. Eichbergs og Bøjes versioner af sportens metafysik vil måske stadig kunne opretholde en kongruent kropskulturel praksis, men de vil have stadig større vanskeligheder med at holde sammen på feltet. Eliteidrættens alliance med $\varnothing$ konomiske interesser fra andre felter synes at have monopoliseret den fascinationskraft, som den virtuelle sport kan kommunikere gennem tv-mediet - og spørgsmålet er, om det ikke er denne repræsentation, flertallet af de sportsinteresserede fremover vil opfatte som sport. Det sociale kan stadig have en vis plads i denne dannelse, men der vil enten blive tale om den symbolske og ukropslige socialitet, der er typisk for tv-mediet, eller om det neo-tribale fællesskab, der findes i fanklubberne. For Verner Møller er der ingen tvivl om, at selvom sporten foretager denne bevægelse, så er dens inderste væsen stadig intakt - eller rettere: Sporten har slet ikke bevæget sig i forhold til sit udgangspunkt, men har i kraft af sine interne potentialer kunnet hegemonisere dele af medierne og erhvervslivet Samtidig er det så $\mathrm{i}$ færd med at skille sig af med de nytte-rationelle regimer, der længe har søgt at kontrollere det.

Objektivt set kan man konkludere, at feltet er i fare for at knække midt over. Dog har de udbredte kritiske reaktioner efter afsløringerne af den systematiserede doping vist, at de moralske og sociale ideer om sport stadig har et vist momentum. Især har reaktionen fra staten og de store idrætsorganisationer en betydelig vægt. ${ }^{53}$ Hvis sporten på afgørende vis mister sin uafhængighed af $\varnothing$ konomiske interesser »mister sin uskyld «, som det er blevet formuleret - vil den ikke længere være et troværdigt gebet for produktion af samfunds- 
mæssige idealer og integrerende social praksis. Statens modoffensiv mod den voksende omsættelighed er dog ikke nødvendigvis en fordel for feltet, som dette forstås af Bøje og især Eichberg, der frygter indflydelse fra et bureaukratisk overvågningssystem, der kan underminere civilsamfundets demokratiske autonomi.

Hele debatten om sportens fremtid i lyset af kommercialiseringen og dopingen har været farvet af varsler om undergang og katastrofer og håb om genfødsel - måske et tidstræk i sig selv, der er typisk for århundredeskifter - for ikke at sige årtusindskifter. Jean Baudrillard skriver, »At profetere katastrofe er utroligt banalt. Det mere originale trak er at formode, at den allerede er indtruffet «. ${ }^{54}$ Eller man kunne med en typisk baudrillardsk frase hævde, at sporten slet ikke eksisterer mere - kun

\section{Noter}

1. Se Levi-Strauss (1977), s. 38 for en videre diskussion af problematikken angående begrebet tabu. Dette begreb minder noget om begrebet »miskendelse «, der betyder, at agenter ikke bevidst erkender, at sociale relationer baseres på dominansforhold. For eksempel udøves vilkårlig symbolsk vold gennem institutioners praksis, som for eksempel skolen, idrætten etc. Dette implicerer udelukkelse af diskurser, der problematiserer grundlaget for den sociale orden.

2. At anskue sporten som særskilt domæne eller livssfære er almindeligt inden for sportssociologien. Eksempelvis forklarer Asplund den moderne konkurrencesports store succes i starten af det 20. århundrede ved, at den netop isolerede sit regime fra det $\varnothing$ vrige samfundsliv. Se Asplund (1979), s. 156. Bourdieus model rækker imidlertid længere end sportens verden. Den sigter mod at generalisere lignende erfaringer fra en række andre praksisformer - kunst, uddannelse, forskning etc. - der alle har en relativt autonom status over for omgivelserne.

3. Selv er regimerne også hver for sig resultater af andre fortidige kampe. en række fysiske aktiviteter uden intern sammenhæng samt en omfattende talestrøm, der i lamenterende toner reproducerer diskurser fra signifikante begivenheder i det 20. århundrede - begivenheder, der vel at mærke er afsluttede. Kun snakken lever stadig, og regimerne segner under vægten af al denne snak. Felter kan ikke overleve uden deres diskrete metafysik, og brydes tabuerne, kan de ikke overleve den italesættelse, der følger. Denne afsluttende påstand vil her få lov til at hænge i luften, men måske undervurderer Baudrillard denne nye diskursivitets evne til at skabe fornyet praksis - der måske nok ikke har meget til fælles med sport, som det var, men som vil arve betegnelsen. Endelig kan man hælde sit hoved til den diskretion, som den uafklarede fremtid fortsat er i besiddelse af.

4. Dette gælder selvsagt ikke for sportssociologien, som netop lever af at foretage analyser af sportens verden. Sportsfeltet er imidlertid ret uberørt af sportssociologien, eftersom denne ikke tilhører sportsfeltet, men derimod det videnskabelige felt, hvor der hersker andre regler.

5. Bourdieu (1993), s. 262.

6. Det er tvivlsomt, om filatelien overhovedet kan betegnes som et felt i bourdieusk forstand. Her bliver det udelukkende anvendt som en illustrativ komparation.

7. Bourdieu (1996b).

8. Bourdieu (1996a), s. 270-271.

9. Bourdieu (1997), s. 97-99. Magtfeltet består selv af en række sub-felter, heriblandt et $\emptyset$ konomisk felt, et juridisk felt og et politisk felt - vi beskæftiger os her især med sidstnævnte.

10. Citeret af Lars Bøgeskov, »Ministerens doping-

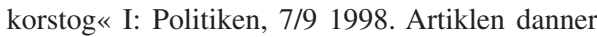
grundlag for hovedparten af empirien i dette afsnit.

11. I andre lande, f.eks. Danmark, er doping ikke direkte ulovligt ifølge landets love. I stedet overlades doping-bekæmpelsen til de respektive forbund. 
12. Politiken, 7/9 1998.

13. Det følgende er baseret på fortløbende udklip fra Politikens sportssider med specielt fokus på Lars Bøgeskovs artikel »Skandalen ruller videre $i$ dag«, 3/8 1998.

14. Med støtte hos Heikkala (Juha Heikkala, »Modernity, Morality and the Logic of Competition « I: International Review for Sociology of Sport, vol. 28/4 (1993) fastslår Inge Kryger Pedersen, at dopingens strukturelle placering i elitesporten bunder i dennes internt betingede konkurrencelogik (Kryger Pedersen (1998), s. 61.

15. Ibid.

16. Ibid.

17. Lars Adam Rehof i radioprogrammet »Orientering, 28/7 1998.

18. Lüschen (1993), s. 97 og 99.

19. Politiken, 27/7 1998.

20. Der findes visse undtagelser - eksempelvis inden for skønhedskirurgien.

21. Her tales generaliserende. Der findes naturligvis miljøer, hvor fitness henholdsvis kokainforbrug er konsensusprægede, men for gennemsnitsborgeren er distinktionen mellem regeneration og maksimering rimelig klar.

22. Der er tale om det spil, som inden for spilteorien kaldes »prisoners dilemma «: To forbrydere er under anklage for et kup, de har begået sammen, men der er ingen beviser. Dømmes de skyldige, vil de hver få tre års fængsel. Samarbejder de med myndighederne, vil de imidlertid få strafnedsættelse til blot ét år. Fangerne er logisk set bedst tjent med ikke at samarbejde (svarende til ikke at dope sig), hvorved de frifindes. Men hvis den anden sladrer (anvender doping), vil den tavse få tre års fængsel (tabe sportskampen og på sigt opgive karrieren), mens den sladrende nøjes med ét år (vinde kampen og fortsætte karrieren). Den individuelle rationalitet (ét år er bedre end tre) vinder derfor over den kollektive, selvom sidstnævnte giver den største samlede nytte.

23. Lars Bøgeskov i Politiken, 7/9 1998.

24. Ideen om »falsk bevidsthed « forudsætter en sand og universel bevidsthed. Men hvis der i det sociale findes mere eller mindre autonome enklaver med deres særegne værdisæt, således som feltteorien påstår, kan bevidstheder aldrig sættes på samme formel. En universel bevidsthed harmonerer ikke med felt-specifiteten - og kravet om universel bevidsthed vil i praksis ofte forekomme ved intervention i fremmede felter.

25. Her er der måske tale om endnu en dansk undta- gelse - en normalisme i betragtning af den danske nationale habitus hvad angår international politisk korrekthed.

26. Analysen er baseret på Michel Foucaults genealogiske metode - her dog i en simplificeret udgave. Schmidt (2000 [1982]). Se også Loshak (1997). Der er blevet foretaget en lang række fors $\varnothing \mathrm{g}$ på at konstruere modeller over sportens kerne-karakteristika - eksempelvis MacAloons distinktion mellem spectacle, festival, game og ritual. Denne har væsentlige lighedspunkter med nærværende regime-model - især at den også understreger betydningen af spillet. MacAloon (1984).

27. Fra forskellige samfundskredse, eksempelvis militæret, virksomheder og staten (Sundhedsministeriet) kan man dog stadig tale om et regime for kollektiv sundhed til fremme af institutionelle mål. Fra videnskabelig side er der divergerende meninger om nytte- og sundhedselementets status i sporten. Inge Kryger Pedersen mener ikke, at sundhedsdimensionen tilhører sportens konstitution, jf. Kryger Pedersen (1998), s. 45. Eftersom sport udelukkende er produktiv i forhold til regelsæt, der ingen forbindelse har til gængse samfundsmæssige produktivitetsnormer, er sport grundlæggende »ikke-utilitaristisk « (denne argumentation er dog ikke helt skudsikker, jf. Munk (1999), kap. 5). Ibid., s. 47. I denne forbindelse trækkes der ofte en skillelinje mellem sport og idræt, hvor sidstnævnte hviler på utilitaristiske værdier og til gengæld ikke besidder førstnævntes konkurrence-moment. Denne holdning knytter sig imidlertid til essentialistiske analyser af sporten. I en genealogisk analyse som i nærværende skrift handler det mere om de historiske betingelser for eksistensen af et autonomt felt for sportslig aktivitet - og i den forbindelse kan man vanskeligt se bort fra den utilitaristiske faktor, der i samspil med andre faktorer har været konstituerende for sportsfeltets faktiske sociale placering.

28. Det er ikke uden grund, at netop fitness-kulturen er en kilde til uro og nervøsitet $\mathrm{i}$ de folkelige idrætsorganisationer. Det er selve feltets autonomi, der er på spil, og der er stor uenigehed om, hvilken strategi man skal vælge i lyset af kulturens stigende popularitet.

29. Et kendt eksempel på løsningen af dette problem er John Rawls' »A Theory of Justice «. Rawls forestiller sig en hypotetisk »oprindelig position«, hvor subjektet frivilligt stiller sig bag »uvidenhedens slør « og dermed mister al sin viden om egen og andres aktuelle position i samfundet. I denne 
situation kan man så enes om den retfærdige indretning af samfundet.

30. Johan Asplund forklarer opkomsten og udbredelsen af den moderne sport ved, at den fungerede som en succesrig håndtering af anomiske tendenser i forbindelse med modernitetens opløsning af traditionelle strukturer. Statusforskelle blev under moderniteten et resultat af indsatser og evner snarere end af nedarvede positioner. Dette medførte, at samfundet blev gennemtrængt af mimetisk rivalitet - en uforsonlig og ødelæggende form for rivalisering. Den moderne sport var i denne forbindelse en måde at ordne denne rivalitet på og isolere den til en adskilt sfære, hvor sejren som et potentielt mål for alle blev mulig, uden at det fik ødelæggende sociale konsekvenser. Asplund (1989). Sportskonkurrencers repetitive karakter er i denne forbindelse central. Kryger Pedersen (1998), s. 60. Inden for sporten danner den enkelte præstation aldrig grundlaget for en cementering af sociale positioner. Spillets reversibilitet, der i tidligere tider forbandt sig til skæbnen, bringes her til at harmonere med den moderne rastløshed og mobilitet.

31. DIF trækker også på denne hammel, men er i kraft af sin sideløbende interesse i eliteidrætten mere splittet.

32. Baudrillard (1997). Dette regime står selvsagt i kraftig opposition til det utilitaristiske regime.

33. Inge Kryger Pedersen mener, at mens kamp og konkurrence (agon) indgår definitorisk i sportsbegrebet, er chanceelementet (alea) ikke konstitutivt, da det ikke indgår i sporten på anden måde, end at sportskonkurrencer sjældent er forudsigelige, jf. Kryger Pedersen (1998), s. 55; se endvidere Munk (1999), kap. 5. Ritualisering af kamp ville imidlertid ikke være mulig uden skabelsen af uafklarethed og chance - og sport udmærker sig netop ved at være en sfære for den evigt genkommende uafklarethed. Denne reversibilitet står hos Baudrillard som en af spillets centrale karakteristika, da den erstatter produktive rationaler med en konstitutiv tomhed. Baudrillard (1997), s. 90. Andetsteds skriver Inge Kryger Pedersen dog, at »Spandingen er et vasentligt element i spфrgsmålet om sportens attraktivitet for såvel dens udфvere som dens tilskuere«. Kryger Pedersen (1998), s. 60 og »Spillets uforudsigelige pendlen $i$ lighedens spandingsfelt for at kulminere med en forskel eksisterer på ethvert stadion « (ibid., s. 114).

34. Martin D. Munk og Jakob Broberg Lind taler om indflydelsen på idrætsfeltet fra et pædagogisk felt og fra et velfærdsideologisk felt, jf. Munk og Broberg Lind (2000). I Danmark holder det politiske felt sig normalt på en vis afstand, da der her hersker et armslængdeprincip svarende til normerne inden for kulturpolitikken. Kan en politisk intervention imidlertid legitimeres på et velfærdsideologisk grundlag, vil idrætsfeltet imidlertid have svært ved at modstå presset, eftersom denne vil indskrive sig i idrætsfeltets egen utilitaristiske logik, der i Danmark netop er tæt forbundet med ideer om almen velfærd.

35. Sporten som skue er mere udførligt analyseret af MacAloon (1984).

36. Bourdieu (1998 [1996]), s. 96.

37. Ibid., s. 97.

38. Henrik Dahl i et foredrag ved DIF's breddeidrætskonference i Idrættens Hus, 20/3 1999.

39. Munk (1999), kap. 5.

40. Bourdieu (1998 [1996]), s. 99. Man må skelne mellem den analytiske Bourdieu og den normative Bourdieu. I bogen om tv taler først og fremmest den normative Bourdieu, mens hans feltanalyse, der anvendes som redskab i denne tekst, er af analytisk art.

41. Ibid.

42. For en mere fyldestgørende diskussion, se Eichberg (1999).

43. Møller (1999), s. 66.

44. Ibid., s. 104-105.

45. Ibid., s. 108 - dette er et Georges Batailles-citat.

46. Ibid., s. 109.

47. Claus Bøje i Politiken, 16/8 1999.

48. Ibid.

49. Ibid.

50. Eichberg (1999).

51. Ibid.

52. Som tidligere omtalt findes der fra akademisk side mange beskrivelser af sportens dramatiske væsen. I den offentlige debat vedrørende doping bliver sådanne positioner imidlertid sjældent ekspliciteret - sandsynligvis fordi ingen af de implicerede stiller spørgsmålstegn ved dette karakteristika.

53. Se f.eks. formanden for Danmarks Idræts-Forbund, Kai Holms kronik i Politiken, 28/8 1998. Kai Holm slår til lyd for, at man bør modarbejde de pengestærke interesser, der er ved at forvandle elitesporten til rent show og bedrag. Dette affødte initiativet til en fællesnordisk doping-resolution, der skulle lægge pres på de »slappe« internationale forbund som f.eks. Den Internationale Cykelunion, UCI. Politiken, 17/9 1998.

54. Baudrillard (1996), s. 68. 


\section{Litteratur}

Asplund, Johan, Rivaler och syndabocker (Göteborg, 1989).

Baudrillard, Jean, Cool Memories II, 1987-1990. Post-Contemporary Interventions (Durham, 1996).

- Forførelse (Frederiksberg, 1997 [1979].

Bourdieu, Pierre: »Program for a Sociology of Sport « I: Sociology of Sport Journal, vol. 5 (1988).

- »The Politics of the body in the Context of Modernity« I: Quest, vol. 43 (1991).

- The Field of Cultural Production (Cambridge, 1993).

- State Nobility - elite schools in the field of power (Cambridge, 1996a [1989]).

- The Rules of Art, Genesis and Structure of the Literary Field (Cambridge, 1996b [1992]).

- Af praktiske grunde: omkring teorien om menneskelig handlen (København, 1997 [1994].

- Om TV - og journalistikkens magt. (København, 1998 [1996].

Bourdieu, Pierre og Loic J.D. Wacquant, Refleksiv Sociologi (København, 1996 [1992].

Bøgeskov, Lars, »Skandalen ruller videre i dag « I: Politiken, 3/8 1998.

Bøje, Claus, »Dopingsvineri« I: Politiken, 16/8 1999.

Eichberg, Henning, »Doping og demokratiets krop« I: Henning Eichberg, Finn Bygballe og Søren Møller (red.), Demokrati og kropslighed - et festskrift ved Gerlev Idrcetshøjskoles 60-års jubilaum (Gerlev, 1999).

Harvey, Jean og Sparks, Robert, »The Politics of the Body in the Context of Modernity « I: Quest, vol. 43 (1991).

Holm, Kai, »Eliteidrætten står ved en skillevej « I: Politiken, 28/8 1998.

Jung, Niels Christian, Den ny orden. Bachelorprojekt ved Danmarks Højskole for Legemsøvelser og Københavns Universitet (København, 1994).
Levi-Strauss, Claude, Structural Antropology 1 (Peregrine Book,1977 [1958].

Loshak, Jeppe, Kulturforvaltning og forvaltningskultur, upubliceret skrift, Institut for Statskundskab, Københavns Universitet (Københan, 1997).

Lüschen, Günther, »Doping in Sport: The Social Structure of a Deviant Culture« I: Sport Science Review, vol. 2 (1993).

MacAloon, John J., »Olympic Games and the Theory of Spectacle in Modern Societies « I: MacAloon (red.), Rite, Drama, Festival, Spectacle. Rehearsals Toward a Theory of Cultural Performance (Philadelphia, 1984).

Munk, Martin D. \& Broberg Lind, Jakob, Idrattens Kulturelle pol - Mellem vardier og politik. 19992000. Kommende udgivelse 2002.

Munk, Martin D., Livsbaner gennem et felt, doktorafhandling, Sociologiska Institutionen, Lunds Universitet (Lund, 1999).

Møller, Verner, Dopingdjavlen - analyse af en hed debat (København, 1999).

Pedersen, Inge Kryger, Den excellente prastation Elitesport, kvinder og karriere. Sociologisk Institut, Københavns Universitet (København, 1998).

Rawls, John, A Theory of Justice (Cambridge Massachusetts, 1999 [1971].

Rehof, Lars Adam, radioprogrammet »Orientering«, 28/7 1998.

Schmidt, Lars-Henrik, »Kroppen i focus: et essay om sport« (Slagelse, 1982).

Wacquant, Loic J.D, »From Ruling Class to Field of Power: An interview with Pierre Bourdieu on La noblesse d'Ètat« I: Theory, Culture and Society, vol. 10 (1993). 